\title{
APPLICATION OF DRY HIGH-INTENSITY MAGNETIC SEPARATION IN UPGRADING LOW-GRADE IRON ORE OF ROUINA DEPOSIT -ALGERIA-
}

\author{
A. Messai1"\#, A. Idres', J.M. Menendez-Aguado² \\ 1 University of Badji Mokhtar, Faculty of Earth Sciences, Mining Department, Laboratory of Mineral \\ Resources Valorization and Environment, Annaba, Algeria \\ 2University of Oviedo, Polytechnic School of Mieres, Mineral Raw Materials Processing \\ Research Group, Spain
}

(Received: April 8, 2020; Accepted: June 2, 2020)

\begin{abstract}
The recent developments of steel and iron industries generated a huge consumption of iron ores which has attracted much attention for utilizing low-grade iron resources to satisfy this increasing demand. The present study focuses on the characterization and enrichment of the low-grade iron ores from Rouina deposit -Ain Defla-. Currently, the ore is used in the cement industry because it is considered a low-grade iron ore. After the sampling process, a physico-chemical and mineralogical characterization was carried out and the results revealed that the sample consists of hematite, limonite and goethite as major opaque oxide minerals whereas silicates as well as clays form the gangue minerals in the sample. The average grade of $\mathrm{Fe}_{\text {Total, }} \mathrm{SiO}_{2}$ and $\mathrm{Al}_{2} \mathrm{O}_{3}$ contents in the raw material collected from the mine of the case study are 30.85\%,23.12\% and $7.77 \%$ respectively. Processes involving combination of classification, washing and dry high-intensity magnetic separation were carried out to upgrade the low-grade iron ore sample to make it suitable as a marketable product. The sample was first ground and each closed size sieve fractions were subjected to washing followed by drying than dry high intensity magnetic separation and it was observed that limited upgradation is possible. As a result, it was possible to obtain a magnetic concentrate of $54.09 \%$ with a recovery degree of $89.30 \%$ and yield of $62.82 \%$ using a magnetic field intensity equal to 2.4 Tesla at the size fraction [-0.125 +0.063 mm].
\end{abstract}

Key words: Rouina; Iron ore; Sampling; Characterization; Washing; Magnetic separation.

\section{Introduction}

The deposits of high-grade iron ore are being exhausted increasingly because of their priority operations in a spirit of economic profitability where the essential part is mainly used in the steel industry [1]. This industry has significantly extended in recent years, and consumers demand of high-grade iron ores cannot be satisfied [2], faced with this challenge, the exploitation and processing of low-grade iron ores has become a necessity [3].

Mineral processing researchers have focused on the enrichment degree and the upgrading of iron ore [4]. The valorization researches of low-grade iron ores are linked with the mineralogical composition, the liberation size and the interaction between different components (iron, silica, alumina, etc.) [5]. The Low-grade iron ores can be enriched to remove gangue minerals by crushing, grinding, gravimetric separation, magnetic separation and flotation $[6,7]$.

Several researchers opted to apply the dry high intensity magnetic separation aiming to enrich low-grade iron ores $[4,8-14,16]$. The results obtained by this method are satisfactory where a maximum product grade of $53.1 \%$ Fetotal $_{\text {is }}$ achievable with $19 \%$ yield as the magnetic product in lift roll magnetic separator (LRMS) at optimum conditions of variables. Rare earth roll magnetic separator (RERMS) is also found to be efficient with a higher yield of $36.8 \%$ in the magnetic product grade of $49.5 \% \mathrm{Fe}_{\text {Total }}$ [9]. Further, magnetic separation studies of low-grade iron ore were carried out by using LRMS and found that a product of maximum of $51.2 \%$ Fetotal can be obtained from the low-grade ore assaying 35.9\% FeTotal [17]. An experiment on a sample contains $56.86 \%$ FeTotal applying dry high intensity magnetic separation with magnetic field equal to $10 \mathrm{~A}$ allowed to upgrade it

\#Corresponding author: ali.messai@hotmail.com

doi: 10.5937/JMMA2001047M 
to $65.40 \%$ [13].

In Algeria there are several mines of iron ore, and Rouina deposit is one of the oldest. Given the fact that the raw material (limonite and goethite) extracted from this mine contains high levels of silica and alumina, it is considered low-grade iron ore so it is intended for cement factories in central and western Algeria, where it is used to control $\mathrm{Fe}$ contents. The needs for raw material for steel industry raised a challenge for mineral processing researchers to seek for upgrading Rouina iron ore.

This study deals with a physico-chemical and mineralogical characterization of Rouina iron ores, and the choice of a treatment method adapted for obtaining a high-grade concentrate meeting the requirements of the market, both on the contents of major and minor elements required by consumers.

\section{Materials and methods}

\subsection{Geographic location}

The ROUINA iron ore deposit is located in the Commune of Rouina, State of Ain Defla, on a dominical field. The national road connects Algiers to Oran as well as the railway line passes $3 \mathrm{~km}$ from the deposit, the geographical situation is presented in figure 1 .

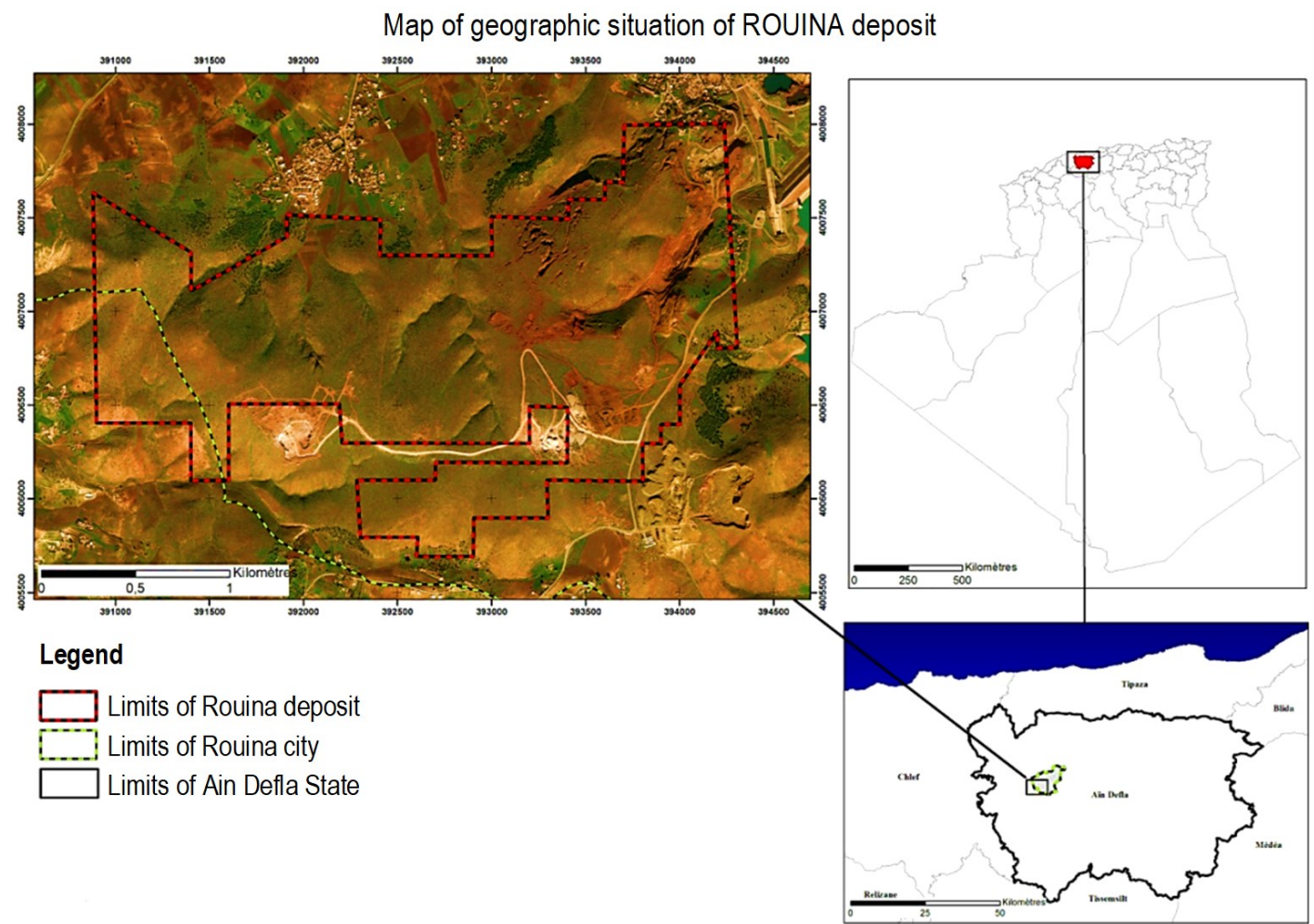

Figure 1 Geographic location of the study area

\subsection{Sampling protocol}

The samples of iron ores were obtained from four different points at the deposit of Rouina with a total weight of $120 \mathrm{~kg}$. They were mixed repeatedly to form a representative sample. The sampling method was random, because this method ensures, as much as possible, that every unit in the lot has an equal chance of being in the sample.

\section{a) Sampling preparation}

The preparation of the samples was carried out in the Laboratory of valorization of mineral resources and environment (LAVAMINE), mining department, Badji Mokhtar - Annaba University. The collected quantity taken from the deposit of Rouina was thoroughly mixed and prepared by conning and quartering to prepare a representative samples. The samples were used for both 
characterization and beneficiation studies including size distribution, physico-chemical and mineralogical analysis, washing and dry magnetic separation tests.

\section{b) Sampling characterization}

The samples were reserved to perform XRD, XRF and microscopy analysis thin sections.

The chemical analysis of raw material was carried out using a spectrometer Bruker-Axs: S8 TIGER equipped with rhodium anode.

The XRD was carried out to identify the mineral phases in the sample (raw material). It was applied using PAN analytical Diffractometer: XPERT-PRO, equipped with Copper Anticathode Ceramic X-ray Tube, the current and voltage were $40 \mathrm{~mA}, 45 \mathrm{kV}$.

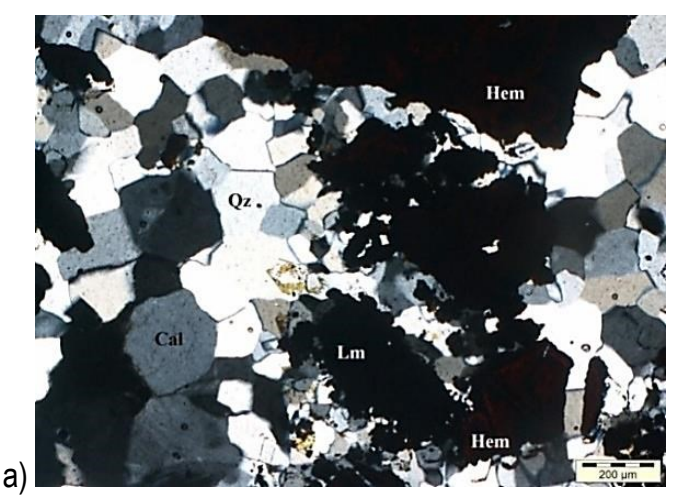

\subsection{Microscopy analysis}

\subsubsection{Optical microscopy}

\subsubsection{Thin section, polarized light}

The thin sections are prepared from the whole sample. The observation of a sample thin section under polarized light (figure 2) shows the presence of xenomorphic quartz as a predominant gangue mineral (figure 2a). Many grains characterized by wavy form indicate that the mineral suffered a mechanic deformation. We note the presence of rare calcite crystals. The figure $2 \mathrm{~b}$ shows that fine particles of hematite and limonite are dissociated in a quartz matrix. Hematite appears sometimes with important mass weakly edged by quartz (figure $2 \mathrm{c}$ ).

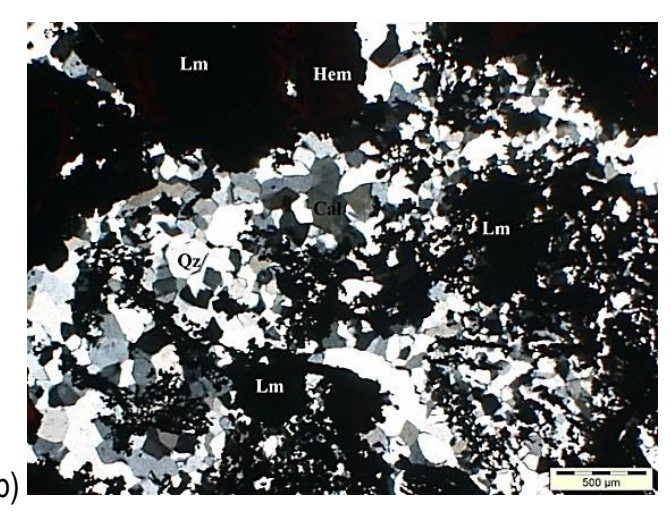

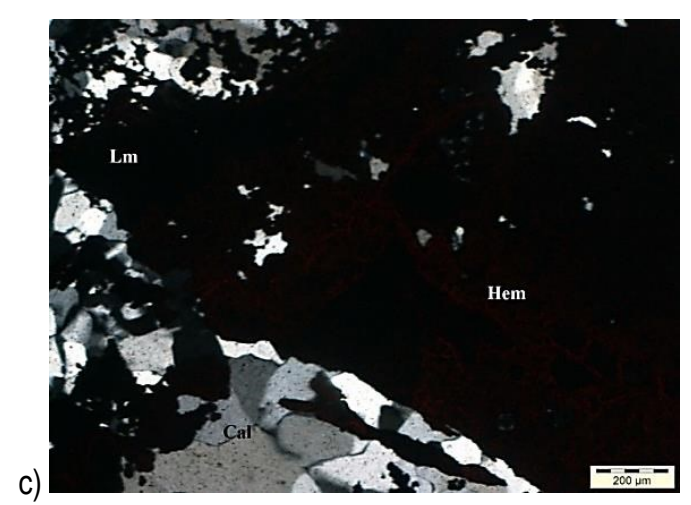

Figure 21 st thin section under polarized light: (a) xenomorphic Quartz to undulating form associated with hematite and presence of rare calcite crystals; (b) Hematite and limonite bathing in a quartz matrix; (c) Hematite mass weakly edged by quartz; (Hem: hematite, Lm: limonite, Qz: quartz and Cal: Calcite)

\subsubsection{Thin section, natural light}

The study of $2^{\text {nd }}$ thin section with natural light allowed us to notice the domination of opaque minerals (Hematite and limonite) surrounded by quartz (figure $3 a$ and $3 b$ ). Some opaque minerals (hematite) show oxidation traces (Limonite) which expressed by brownish spots (figure 3c and $3 d$ ). 
a)
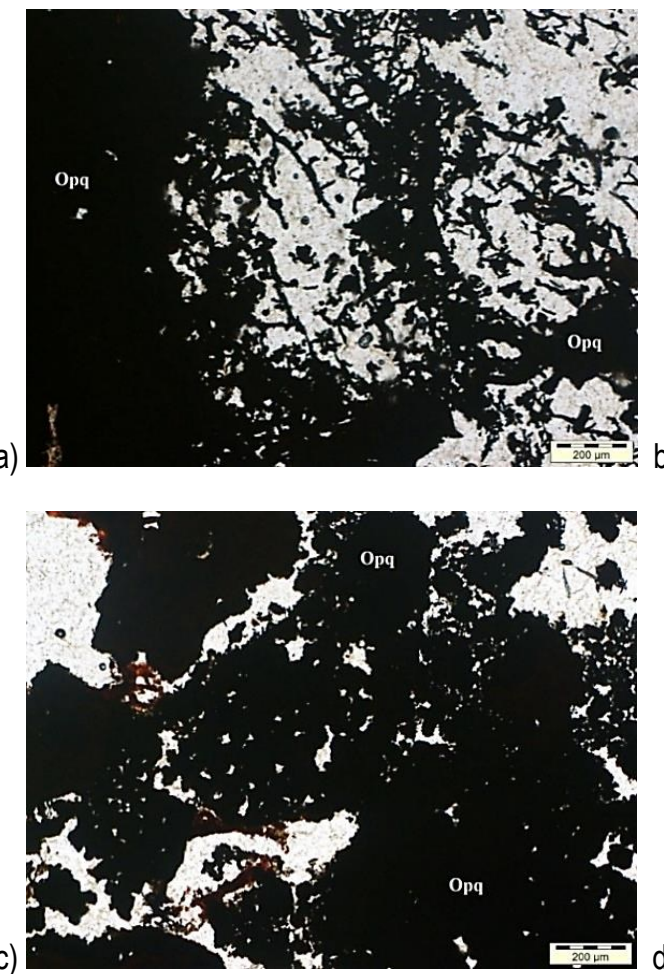
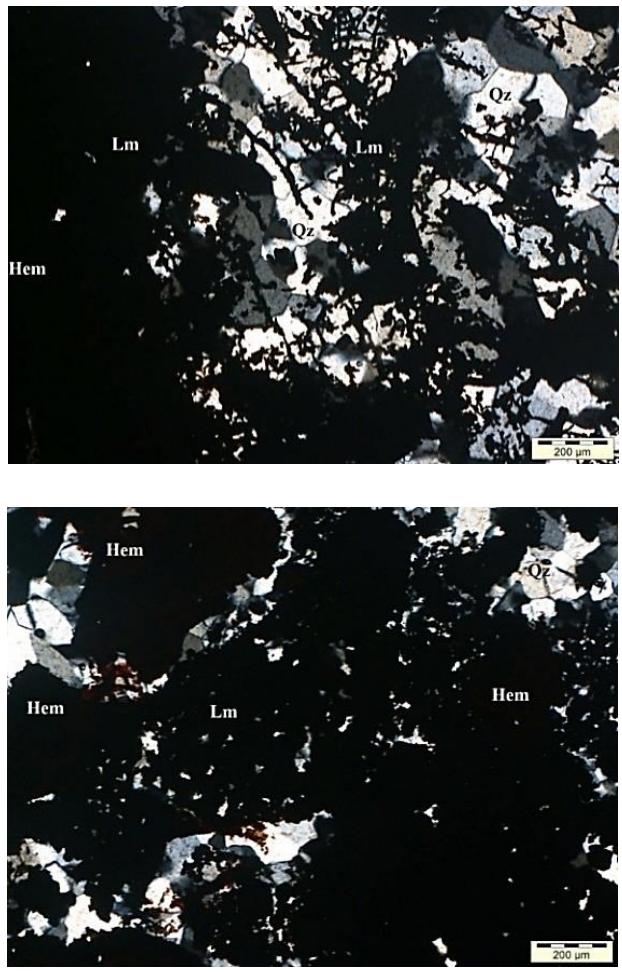

Figure $32^{\text {nd }}$ thin section under natural light (Hem: hematite, Lm: limonite and Qz: quartz)

\subsubsection{Metallographic microscopy}

The observation with a metallographic microscope confirms the presence of limonite with yellow, yellow orange and yellow brownish colors as a major mineral (figure 4a). The hematite with black greenish shows a border with a different alteration rate (figure $4 b$ ). This alteration consists in the change of color from the center of particles to the edge, from hematite to limonite (black to yellow). The blue dotes indicates as air bubbles created in the thin section preparation steps.
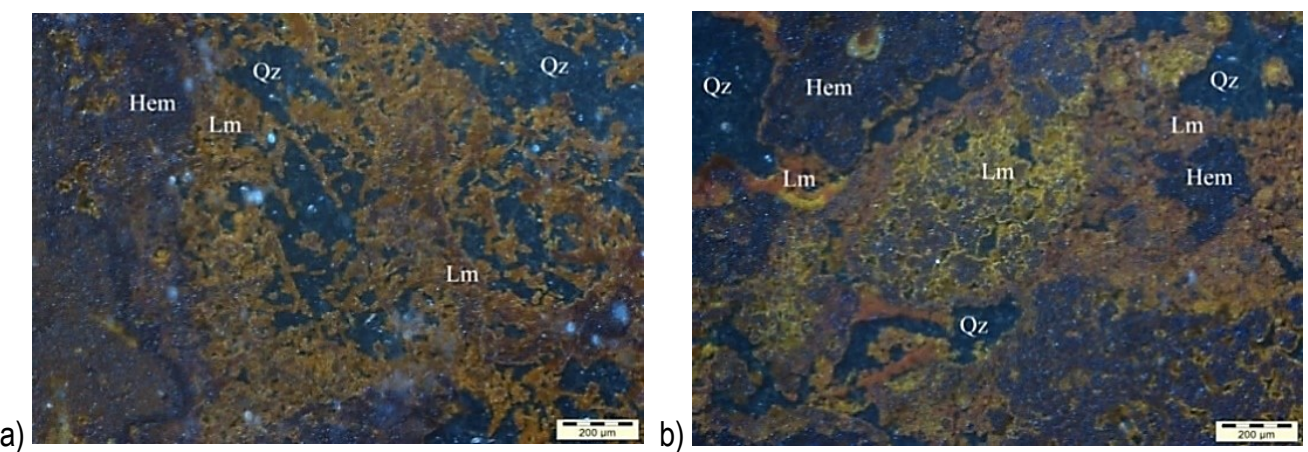

Figure 4 Microphotographs of metallographic microscope (Hem: hematite, Lm: limonite and Qz: quartz)

\subsection{Sieve analysis}

The size analysis was operated using quantity of 600 grams of dried raw material crushed to $<4 \mathrm{~mm}$, a shaking machine type RETSCH and sieves series assembly of: 4 , $2,1,0.5,0.25,0.125$ and $0.063 \mathrm{~mm}$. the sample is sieved for 30 minutes with magnitude of $60 \mathrm{~mm} / \mathrm{g}$. The refusal mass of each sieve is weighed using a scale with an 
accuracy of $0.01 \mathrm{~g}$.

The results of sieving analysis are presented in

coarser fraction $[-5+2 \mathrm{~mm}]$ by $46.96 \%$ ( 281.77 grams).

Table 1. The majority mass, $46.96 \mathrm{w} \%$, appears in the

The rest of product is divided in the other size fractions.

Table 1 Results of particle size analysis of Rouina iron ore crushed to $5 \mathrm{~mm}$ [18]

\begin{tabular}{|c|c|c|c|c|}
\hline $\begin{array}{c}\text { Particle size class } \\
(\mathrm{mm})\end{array}$ & \multirow{2}{*}{ Weight $(\mathrm{g})$} & \multicolumn{3}{|c|}{ Yields (\%) } \\
\cline { 3 - 5 } & 281.77 & Partial & Cumulative undersize & Cumulative oversize \\
\hline+2 & 86.96 & 100 & 0 \\
\hline+1 & 64.03 & 14.91 & 53.04 & 46.96 \\
\hline+0.5 & 51.25 & 10.67 & 38.13 & 61.87 \\
\hline+0.25 & 50.72 & 8.54 & 27.46 & 72.54 \\
\hline+0.125 & 41.44 & 6.91 & 18.92 & 81.08 \\
\hline+0.063 & 21.37 & 3.56 & 10.47 & 89.53 \\
\hline+0 & 600 & 100 & 3.56 & 96.44 \\
\hline TOTAL & & & $/$ & $/$ \\
\hline
\end{tabular}

\subsection{XRF analysis}

The results of the analysis are shown in Table 2; we note the dominance of the iron content in the chemical composition of ore with $30.85 \%$. The gangue components consist of silica, alumina and calcite with $23.12 \%, 7.77 \%$ and $5.51 \%$ respectively. These results mean that the ore studied is a hematite - silica - clay iron ore with calcite inclusions.

Table 2 XRF Analysis of Raw material

\begin{tabular}{|c|c|c|c|c|c|c|c|c|c|c|c|c|}
\hline Fetotal & $\mathrm{SiO}_{2}$ & $\mathrm{Al}_{2} \mathrm{O}_{3}$ & $\mathrm{CaO}$ & $\mathrm{MgO}$ & $\mathrm{P}_{2} \mathrm{O}_{5}$ & $\mathrm{SO}_{3}$ & $\mathrm{~K}_{2} \mathrm{O}$ & $\mathrm{TiO}_{2}$ & $\mathrm{MnO}$ & $\mathrm{ZnO}$ & $\mathrm{BaO}$ & $\mathrm{LOI}$ \\
\hline 30.85 & 23.12 & 7.77 & 5.51 & 1.37 & 0.12 & 0.35 & 0.95 & 0.28 & 0.32 & 0.38 & 0.76 & 14.01 \\
\hline
\end{tabular}

\subsection{XRD analysis}

The diffractogram obtained is presented on the spectrum shown in Figure 5. It shows the dominant presence of iron oxides (hematite and goethite) and quartz. It also shows the presence of illite in addition to calcite as minerals associated with the components of interest.

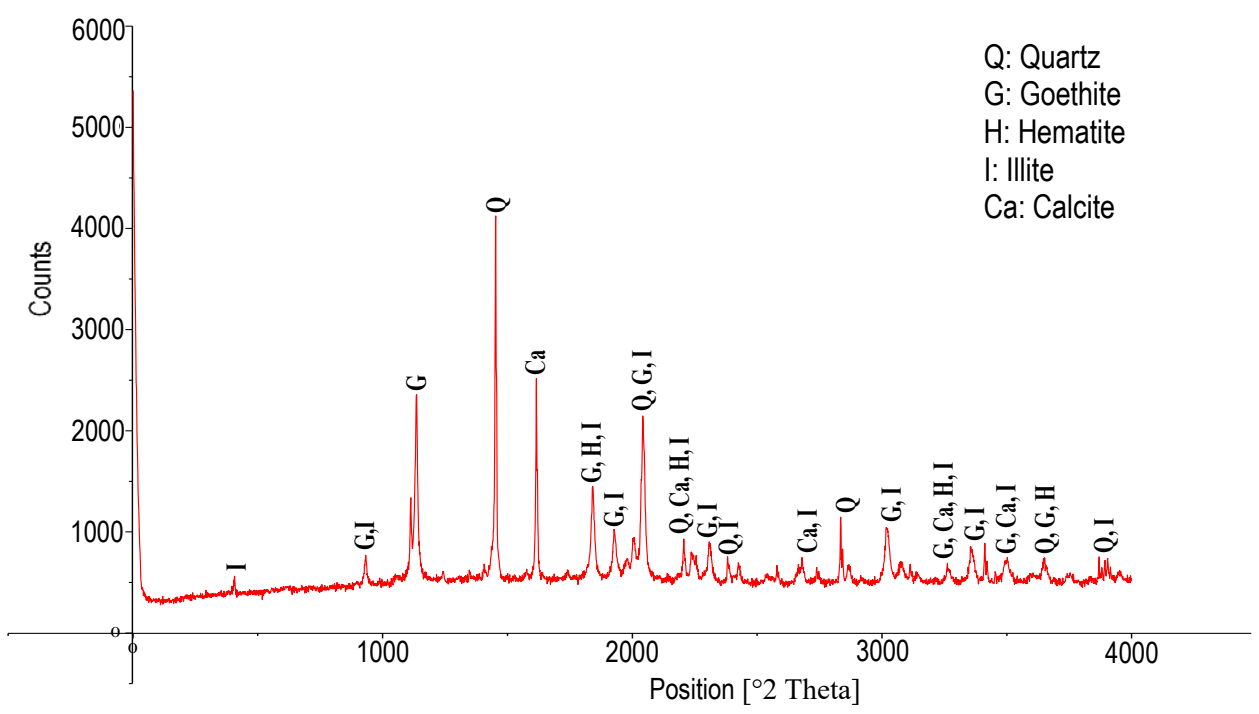

Figure $5 \mathrm{X}$-ray diffraction spectrum of Rouina iron ore (raw material) 


\subsection{Ore beneficiation procedure}

The experimental flowsheet is shown in Figure 6 and includes procedures as follows: grinding and sieving of raw ore, washing and drying of mass passed through the sieve, and finally magnetic separation of dried product. Raw ore was ground and sieved to limit the maximum particle size to $1 \mathrm{~mm}$. The portion of fine particles with sizes below $1 \mathrm{~mm}$ was washed with a sieve of 45 microns aperture, under water flow rate equal to $0.35 \mathrm{~m}^{3} / \mathrm{h}$ until the total cleaning of samples from clays. The retained mass of sieve was dried in an oven at $105{ }^{\circ} \mathrm{C}$ for 24 hours. The dried products were continuously fed through the hopper by vibratory feeder to an induced roll magnetic separator type 138TT42 shown in Figure 7, where the magnetic field is generated by 8 bobbins on a rotor characterized by a diameter of $100 \mathrm{~mm}$ and rotation speed equal to $55-60 \mathrm{rpm} / \mathrm{min}$. the nominal power of the separator motor is $0.25 \mathrm{Kw}$. Magnetic separation tests were performed at three different magnetic field intensities ( $5 \mathrm{~A}=1.4 \mathrm{~T}, 10 \mathrm{~A}=1.9 \mathrm{~T}$ and $12 \mathrm{~A}=2.4 \mathrm{Tesla})$, on samples weighing 100 grams each. The tests were repeated three times for ensuring the reliability of results.

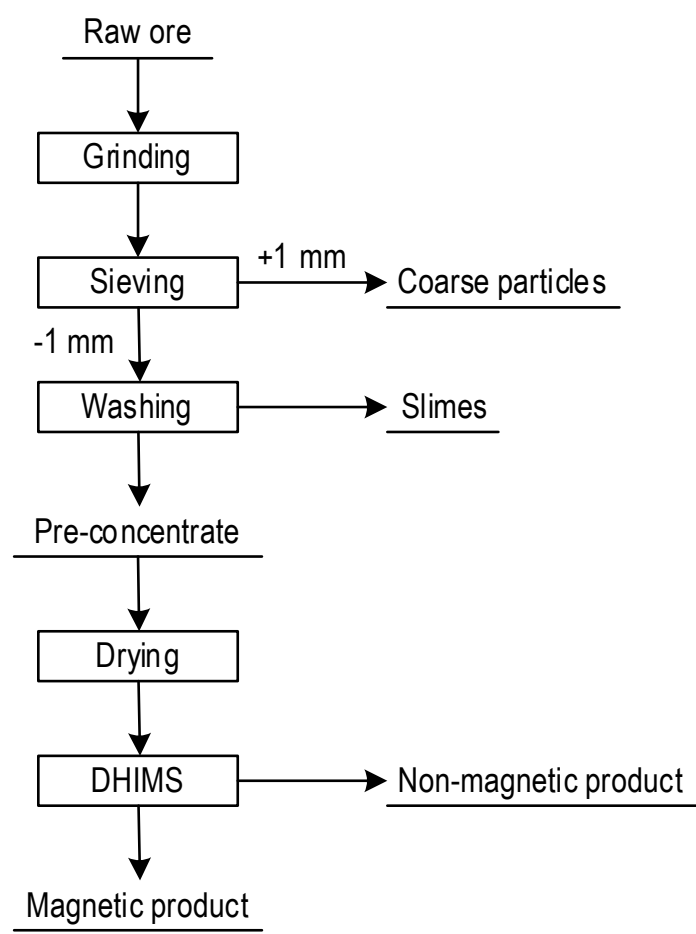

Figure 6 Diagram of experimental procedure

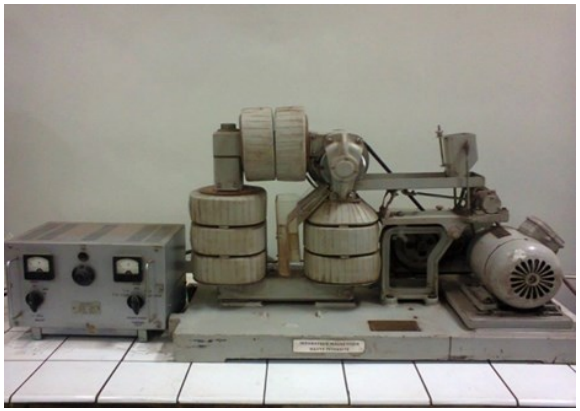

Figure 7 Dry high intensity magnetic separator

\subsection{Statistical analysis}

In order to confirm and verify the reliability of the obtained results for each experiment, a statistical model, which estimates errors of magnetic separation efficiency under different factors variation, was applied. Table 3 presents the different parameters with their formulas. It can be seen that ta presents Student coefficient which is determined according to liberation degree $(\mathrm{n}-1)$ and probability associated to the confidence interval $(P=95 \%)$ so $t_{a}=2.36$. 
Table 3 Parameters and formulas of statistical modal

\begin{tabular}{|c|c|c|}
\hline Parameters & Symbols & Formulas \\
\hline Average grade of iron oxide & $\bar{X}$ & $\frac{1}{n} \sum_{i=1}^{n} X_{i}$ \\
\hline Standard deviation & $S$ & $\sqrt{\frac{\sum_{i=1}^{n}(\bar{X}-X i)^{2}}{n-1}}$ \\
\hline Sampling probable error & $E$ & $\frac{S \times t_{a}}{\sqrt{n}}$ \\
\hline Average coefficient of variation & $K_{\text {var }}$ & $\frac{S}{\bar{X}} \times 100$ \\
\hline Relative error & $\Xi$ & $E$ \\
\hline Major average tenor of iron oxide & $\bar{X}^{\text {maj }} \times 100$ \\
\hline Minor average tenor of iron oxide & $\bar{X}^{\text {min }}$ & $\bar{X}+E$ \\
\hline
\end{tabular}

\section{Results and discussion}

\subsection{Washing test results}

Particle size fractions prepared by sieving analysis are subjected to washing tests. The tests were aimed at separating of useful minerals (ore particles) from the mainly gangue of clay, calcite and quartz. It should be mentioned that each size class retained was put in a sieve suitable for carrying out the washing operation by a jet of water. The chemical analysis results of different size classes before and after washing are showed in the Table 4.

Table 4 XRF analysis of washed and unwashed products

\begin{tabular}{|c|c|c|c|c|c|c|}
\hline Fraction $(\mathrm{mm})$ & Process & $\mathrm{Fe}_{\text {Total }}$ & $\mathrm{SiO}_{2}$ & $\mathrm{Al}_{2} \mathrm{O}_{3}$ & $\mathrm{CaO}$ & $\mathrm{MgO}$ \\
\hline \multirow{2}{*}{$-1+0.5$} & before washing & 30.89 & 23.13 & 7.87 & 6.53 & 1.13 \\
\cline { 2 - 7 } & after washing & 35.68 & 20.20 & 1.45 & 7.57 & 0.40 \\
\hline \multirow{2}{*}{$-0.5+0.25$} & before washing & 30.61 & 22.26 & 6.96 & 6.22 & 1.06 \\
\cline { 2 - 7 } & after washing & 34.60 & 19.19 & 1.78 & 8.22 & 0.47 \\
\hline \multirow{2}{*}{$-0.25+0.125$} & before washing & 32.47 & 18.09 & 8.48 & 3.73 & 1.91 \\
\cline { 2 - 7 } & after washing & 36.36 & 14.81 & 1.96 & 7.69 & 0.59 \\
\hline \multirow{2}{*}{$-0.125+0.063$} & before washing & 32.43 & 18.97 & 8.55 & 3.78 & 2.13 \\
\cline { 2 - 7 } & after washing & 38.05 & 16.30 & 1.53 & 6.17 & 0.51 \\
\hline \multirow{2}{*}{$-1+0.063$} & before washing & 31.77 & 22.06 & 7.53 & 5.08 & 1.45 \\
\cline { 2 - 7 } & after washing & 35.25 & 19.25 & 1.64 & 7.62 & 0.50 \\
\hline
\end{tabular}

According to the results obtained, it's indicated an increasing of iron content for all size fractions and also for the total sample [-1+0.063 mm], it's noted too a significant decreasing of alumina to $1.45 \%, 1.78 \%, 1.96 \%, 1.53 \%$ and 1.64 against $7.87 \%, 6.96 \%, 8.48 \%, 8.55$ and $7.53 \%$ in the unwashed raw material respectively. 


\subsection{Slimes analysis}

The fines remaining after washing process of total sample $[-1+0.063 \mathrm{~mm}]$ are analyzed by X-Ray Fluorescence (XRF) and the obtained results are shown in Table 5.

Table $5 \mathrm{XRF}$ results of washing test rejects

\begin{tabular}{|c|c|c|c|c|}
\hline Fe Total & $\mathrm{SiO}_{2}$ & $\mathrm{Al}_{2} \mathrm{O}_{3}$ & $\mathrm{CaO}$ & $\mathrm{MgO}$ \\
\hline 20.45 & 17.83 & 21.22 & 0.43 & 3.23 \\
\hline
\end{tabular}

It can be noticed that it contains a high content of alumina and silica assaying $21.22 \%$ and $17.83 \%$ respectively against a low content of iron which is equal to $20.45 \%$ Fetotal.

\subsection{Enrichment process}

\subsubsection{Magnetic products analysis}

A series of tests on total sample and samples of different size classes at different intensities were carried out. The XRF analysis results of magnetic and non-magnetic fractions are presented in the tables 6 and 7 . The tables show also the yield, and recovery degree.

Table 6 Results of magnetic separation studies of classified ore

\begin{tabular}{|c|c|c|c|c|c|}
\hline Size class $(\mathrm{mm})$ & Intensity $(\mathrm{T})$ & Detail & Yield (\%) & Fetotal & Fe recovery \\
\hline \multirow{2}{*}{$-1+0.500$} & \multirow{8}{*}{2.4} & Magnetic & 50.98 & 48.21 & 68.88 \\
\hline & & Non-magnetic & 49.02 & 22.65 & 31.12 \\
\hline \multirow{2}{*}{$-0.500+0.250$} & & Magnetic & 52.17 & 49.49 & 74.62 \\
\hline & & Non-magnetic & 47.83 & 18.36 & 25.38 \\
\hline \multirow{2}{*}{$-0.250+0.125$} & & Magnetic & 59.75 & 52.50 & 86.27 \\
\hline & & Non-magnetic & 40.25 & 12.40 & 13.73 \\
\hline \multirow{2}{*}{$-0.125+0.063$} & & Magnetic & 62.82 & 54.09 & 89.30 \\
\hline & & Non-magnetic & 37.18 & 10.95 & 10.70 \\
\hline \multirow{2}{*}{$-1+0.500$} & \multirow{8}{*}{1.9} & Magnetic & 50.47 & 45.67 & 64.60 \\
\hline & & Non-magnetic & 49.53 & 25.50 & 35.40 \\
\hline \multirow{2}{*}{$-0.500+0.250$} & & Magnetic & 52.44 & 45.98 & 68.69 \\
\hline & & Non-magnetic & 47.56 & 22.77 & 31.31 \\
\hline \multirow{2}{*}{$-0.250+0.125$} & & Magnetic & 57.55 & 48.86 & 77.33 \\
\hline & & Non-magnetic & 42.45 & 19.41 & 22.67 \\
\hline \multirow{2}{*}{$-0.125+0.063$} & & Magnetic & 60.33 & 50.22 & 79.62 \\
\hline & & Non-magnetic & 39.67 & 19.54 & 20.38 \\
\hline \multirow{2}{*}{$-1+0.500$} & \multirow{8}{*}{1.4} & Magnetic & 42.10 & 43.13 & 50.89 \\
\hline & & Non-magnetic & 57.90 & 30.26 & 49.11 \\
\hline \multirow{2}{*}{$-0.500+0.250$} & & Magnetic & 45.19 & 44.83 & 58.55 \\
\hline & & Non-magnetic & 54.81 & 26.16 & 41.45 \\
\hline \multirow{2}{*}{$-0.250+0.125$} & & Magnetic & 53.79 & 45.02 & 66.60 \\
\hline & & Non-magnetic & 48.21 & 25.19 & 33.40 \\
\hline \multirow{2}{*}{$-0.125+0.063$} & & Magnetic & 54.14 & 47.11 & 67.03 \\
\hline & & Non-magnetic & 47.86 & 26.21 & 32.97 \\
\hline
\end{tabular}


The results of the tests on different size fractions leaded on the dry high intensity magnetic separator are encouraging where we can see a significant increase of iron ore content. The best result is for the size fraction $[-0.125+0.063 \mathrm{~mm}]$ at field intensity of $2.4 \mathrm{~T}$ where the iron content is increased from $38.05 \%$ to $54.09 \%$ with a recovery degree and yield equal to $89.30 \%$ and $62.82 \%$ respectively. The increase in iron values in case of finer size fractions is due to increase in liberation degree.

The results of the tests on total sample $[-1+0.063$ $\mathrm{mm}$ ] are significant, the best result obtained is at the maximum intensity of magnetic field of 2.4 Tesla where it's noted an increasing of iron content from $35.25 \%$ to $51.54 \%$ with a recovery degree of $84.52 \%$ and a yield equal to $57.81 \%$.

Table 7 Results of magnetic separation studies of total sample

\begin{tabular}{|c|c|c|c|c|c|}
\hline Size fraction & Intensity $(\mathrm{T})$ & Detail & Yield (\%) & FeTotal & Fe recovery \\
\hline \multirow{4}{*}{2.4} & Magnetic & 57.81 & 51.54 & 84.52 \\
\cline { 2 - 5 } & \multirow{2}{*}{2.0 .063} & Non-magnetic & 42.02 & 12.98 & 15.48 \\
\cline { 2 - 5 } & \multirow{2}{*}{1.9} & Magnetic & 52.17 & 49.19 & 72.80 \\
\cline { 2 - 5 } & \multirow{2}{*}{1.4} & Non-magnetic & 47.83 & 20.05 & 27.20 \\
\cline { 2 - 5 } & & Magnetic & 45.25 & 46.32 & 59.46 \\
\cline { 2 - 5 } & & Non-magnetic & 54.75 & 26.10 & 40.54 \\
\hline
\end{tabular}

\subsubsection{Statistical analysis}

The statistical model was applied in order to verify the reliability of results achieved by magnetic separation. The obtained results are presented in Tables 8 and 9, it's noted that the reliability is realized for all tests where the sampling maximum error does not exceed threefold of standard deviation ( $E \leq 3 S)$.

Table 8 Results of statistical analysis of size fractions magnetic separation results

\begin{tabular}{|c|c|c|c|c|c|c|c|c|c|c|c|c|}
\hline Intensity $(\mathrm{T})$ & \multicolumn{4}{|c|}{2.4} & \multicolumn{4}{|c|}{1.9} & \multicolumn{4}{|c|}{1.4} \\
\hline $\begin{array}{l}\text { Size fraction } \\
(\mathrm{mm})\end{array}$ & -1 & -0.5 & -0.25 & -0.125 & -1 & -0.5 & -0.25 & -0.125 & -1 & -0.5 & -0.25 & -0.125 \\
\hline Test $N^{\circ}=01$ & 48.14 & 49.25 & 52.09 & 54.15 & 45.83 & 44.55 & 48.28 & 50.09 & 42.90 & 44.65 & 45.04 & 47.45 \\
\hline Test $\mathrm{N}^{\circ}=02$ & 48.03 & 49.73 & 52.49 & 54.07 & 45.67 & 45.96 & 48.49 & 50.21 & 43.37 & 44.80 & 44.92 & 47.42 \\
\hline Test $\mathrm{N}^{\circ}=03$ & 48.53 & 49.41 & 52.33 & 53.63 & 45.33 & 45.65 & 48.78 & 50.60 & 43.24 & 44.95 & 45.29 & 47.03 \\
\hline $\begin{array}{l}\text { Average } \\
\text { grade }\end{array}$ & 48.23 & 49.46 & 52.30 & 53.95 & 45.61 & 45.72 & 48.52 & 50.30 & 43.17 & 44.80 & 45.08 & 47.30 \\
\hline $\begin{array}{l}\text { Standard } \\
\text { deviation }\end{array}$ & 0.26 & 0.24 & 0.16 & 0.28 & 0.26 & 0.21 & 0.25 & 0.26 & 0.24 & 0.15 & 0.19 & 0.23 \\
\hline $\begin{array}{c}\text { Sampling } \\
\text { probable error }\end{array}$ & 0.35 & 0.33 & 0.22 & 0.38 & 0.35 & 0.29 & 0.34 & 0.35 & 0.33 & 0.20 & 0.26 & 0.31 \\
\hline $\begin{array}{c}\text { Average } \\
\text { coefficient of } \\
\text { variation }\end{array}$ & 0.54 & 0.48 & 0.31 & 0.52 & 0.57 & 0.46 & 0.52 & 0.52 & 0.56 & 0.33 & 0.42 & 0.49 \\
\hline Relative error & 0.72 & 0.68 & 0.42 & 0.70 & 0.77 & 0.64 & 0.70 & 0.70 & 0.76 & 0.45 & 0.58 & 0.65 \\
\hline $\begin{array}{l}\text { Major average } \\
\text { grade of iron }\end{array}$ & 48.48 & 49.79 & 52.52 & 54.33 & 45.96 & 46.01 & 48.86 & 50.65 & 43.50 & 45.00 & 45.34 & 47.61 \\
\hline $\begin{array}{c}\text { Minor average } \\
\text { grade of iron }\end{array}$ & 47.88 & 49.13 & 52.08 & 53.57 & 45.26 & 44.43 & 48.18 & 49.95 & 42.84 & 44.60 & 44.82 & 46.99 \\
\hline $\begin{array}{l}\text { Number of } \\
\text { required tests }\end{array}$ & 8 & 8 & 8 & 8 & 8 & 8 & 8 & 8 & 8 & 8 & 8 & 8 \\
\hline
\end{tabular}


Table 9 Results of statistical analysis of total sample magnetic separation results

\begin{tabular}{|c|c|c|c|}
\hline Sample & \multicolumn{3}{|c|}{$-1+0.063 \mathrm{~mm}$} \\
\hline Intensity $(\mathrm{T})$ & 2.4 & 1.9 & 1.4 \\
\hline${\text { Test } \mathrm{N}^{\circ}=01}^{\circ}$ & 51.24 & 49.41 & 46.25 \\
\hline${\text { Test } \mathrm{N}^{\circ}=02}^{0}$ & 51.60 & 49.52 & 46.39 \\
\hline Test $\mathrm{N}^{\circ}=03$ & 51.33 & 49.19 & 46.89 \\
\hline Average grade & 51.39 & 49.37 & 46.51 \\
\hline Standard deviation & 0.19 & 0.21 & 0.34 \\
\hline Sampling probable error & 0.26 & 0.29 & 0.46 \\
\hline Average coefficient of variation & 0.37 & 0.41 & 0.70 \\
\hline Relative error & 0.50 & 0.57 & 0.95 \\
\hline Major average grade of iron & 51.65 & 49.66 & 46.97 \\
\hline Minor average grade of iron & 51.13 & 49.08 & 46.05 \\
\hline Number of required tests & 8 & 8 & 8 \\
\hline
\end{tabular}

\section{Conclusion}

The investigations carried out on the low-grade iron ore issue of Rouina deposit reveal the following conclusions.

(1) The chemical analysis proved that the original sample collected from Rouina deposit is low-grade iron ore with high content of quartz and alumina where it contains $30.85 \% \mathrm{Fe}_{\text {Total }}, 23.12 \% \mathrm{SiO}_{2}$ and $7.77 \% \mathrm{Al}_{2} \mathrm{O}_{3}$.

(2) Regarding mineralogical characterization, the study carried out on the washed samples over thin sections and binocular observations, and with DRX, confirms that the mineral phase mainly observed is hematite-quartz-clay containing some inclusions of calcite.

(3) According to the results obtained from the chemical analysis (after the washing process by wet sieving) of the different size classes, a significant decrease in alumina content can be noticed after washing; additionally, the iron content increases up and that confirms the significant results obtained by this preconcentration via wet sieving.

(4) Dry high-intensity magnetic separation (DHIMS) has been produced a good quality of iron ore. The best result is for the size fraction $[-0.125+0.063 \mathrm{~mm}]$ at field intensity of $2.4 \mathrm{~T}$ where the iron content is increased from $38.05 \%$ to $54.09 \%$ with a recovery degree and yield equal to $89.30 \%$ and $62.82 \%$ respectively.

(5) The application of statistical model allowed estimating the errors of each experiment in order to verify the reliability of enrichment process results.

\section{Acknowledgments}

The author's gratefully acknowledge: Professor Hadj Zobir Souraya, Geology Department, Earth Sciences Faculty, University of Badji Mokhtar -Annaba- Algeria. Engineers of XRF, XRD and SEM at Division of Technologies and Development (DTD), SONATRACH subsidiary -Boumerdes-. Engineers and all the staff of Rouina deposit. Djabri Mohamed Tayeb, PhD student, earth sciences and architecture faculty, University of Larbi Ben M'hidi -Oum Bouaghi- Algeria and Doctor Linda Merzougui, Sociolinguistic Studies, West of Scotland University, United Kingdom for their support to conduct this research work.

\section{References}

[1] Ferreira, H., Leite, M.G.P. (2015) A Life Cycle Assessment study of iron ore mining. Journal of cleaner production, 108, 1081-1091.

[2] Nomura, T., et al. (2015) Beneficiation Plants and Pelletizing Plants for Utilizing Low Grade Iron Ore. Kobelco Technology Review 33, 8-15.

[3] Poperechnikova, O.Y., Filippov, L.O., Shumskaya, E.N., Filippova, I.V. (2017) Intensification of the Reverse Cationic Flotation of Hematite Ores with Optimization of Process and Hydrodynamic Parameters of Flotation Cell. In Journal of Physics: Conference Series (Vol. 879, No. 1, p. 12-16).

[4] He, J., Liu, C., Xie, J., Hong, P., Yao, Y. (2017) Beneficiation of coarse particulate iron ore by using 
a dry density-based fluidized bed separator. Powder Technology, 319, 346-355.

[5] Rath, S.S., Dhawan, N., Rao, D.S., Das, B., Mishra, B.K. (2016) Beneficiation studies of a difficult to treat iron ore using conventional and microwave roasting. Powder Technology, 301, 1016-1024.

[6] Jankovic, A. (2015) Developments in iron ore comminution and classification technologies. In: Iron Ore: Mineralogy, Processing and Environmental Sustainability, Woodhead publications, Elsevier, Cambridge, pp. 251-282.

[7] Xiong, D. Lu, L. Holmes, R.J. (2015) Developments in the physical separation of iron ore: magnetic separation. In: Iron Ore: Mineralogy, Processing and Environmental Sustainability, Woodhead publications, Elsevier, Cambridge, pp. 283-307.

[8] Tripathy, S.K., Suresh, N. (2017) Influence of particle size on dry high-intensity magnetic separation of paramagnetic mineral. Advanced Powder Technology, 28(3), 1092-1102.

[9] Tripathy, S.K., Singh, V., Murthy, Y.R., Banerjee, P.K., Suresh, N. (2017) Influence of process parameters of dry high intensity magnetic separators on separation of hematite. International Journal of Mineral Processing, 160, 16-31.

[10] Hosseinzadeh, M., Alizadeh, M., Raouf Hosseini, S.M. (2017) Mineralogical and physical beneficiation studies for iron extraction from Bardaskan titanomagnetite placer deposit. Journal of Mining and Environment, 8(2), 191-201.

[11] Su, T., Chen, T., Zhang, Y., Hu, P. (2016) Selective Flocculation Enhanced Magnetic Separation of Ultrafine Disseminated Magnetite
Ores. Minerals, 6(3), 86.

[12] Qiu, T., Wu, C., Ai, G., Zhao, G., Yu, X. (2015) Effects of Multi-stage Grinding Process and Grinding Fineness on Desulfurization Separation of Highsulfurous Iron Ore. Procedia engineering, 102, 722730.

[13] Liu, D., Li, J.L., Wen, S.M., Wang, Y.J., Chen, Y., Cui, C. F. (2015) Beneficiation Experiment Study on Iron Ore in Yunnan Province. Applied Mechanics and Materials (Vol. 737, pp. 813-816). Trans Tech Publications.

[14] Dwari, R.K., Rao, D.S., Reddy, P.S.R. (2014) Mineralogical and beneficiation studies of a lowgrade iron ore sample. Journal of The Institution of Engineers (India): Series D, 95(2), 115-123.

[15] Chen, C.Y., Wen, S.M., Xian, Y.J., Feng, Q.C., Zhao, H.F. (2013) Recovery of Iron from Tailings of Yangla Copper Ore by Magnetic Separation. In Advanced Materials Research (Vol. 634, pp. 3442-3445). Trans Tech Publications.

[16] Kim, J.R., Lee, Y.S., Min, D.J., Jung, S.M., Yi, S.H. (2004) Influence of $\mathrm{MgO}$ and $\mathrm{Al}_{2} \mathrm{O}_{3}$ contents on viscosity of blast furnace type slags containing $\mathrm{FeO}$. ISIJ international, 44(8), 1291-1297.

[17] Tripathy, S.K., Banerjee, P.K., Suresh, N. (2014) Separation analysis of dry high intensity induced roll magnetic separator for concentration of hematite fines, Powder Technol. 264, 527-535.

[18] Messai, A., Idres, A., Benselhoub, A. (2018) Mineralogical characterization of limonitic iron ore from the Rouina mine, Ain Defla (Algeria). Journal of Geology, Geography and Geoecology, 27(2), 305315. 


\title{
PRIMENA SUVE MAGNETNE SEPARACIJE VISOKOG INTENZITETA NA OBOGAĆIVANJE NISKOPROCENTNE RUDE GVOŽĐA IZ RUDNOG LEŽIŠTA ROUINA, ALŽIR
}

\author{
A. Messai ${ }^{1 \#,}$ A. Idres ${ }^{1}$, J.M. Menendez-Aguado² \\ 1 University of Badji Mokhtar, Faculty of Earth Sciences, Mining Department, Laboratory of Mineral \\ Resources Valorization and Environment, Annaba, Algeria \\ 2University of Oviedo, Polytechnic School of Mieres, Mineral Raw Materials Processing \\ Research Group, Spain
}

(Primljen: 8. april 2020.; Prihvaćen: 2. jun 2020.)

\begin{abstract}
Izvod
Nedavni razvoj industrije čelika i gvožđa je prouzrokovao veliku potrošnju rude gvožđa što je skrenulo pažnju na iskorišćenje resursa niskoprocentne rude gvožđa kako bi se ova sve veća potražnja zadovoljila. Ovaj rad se bavi karakterizacijom $i$ obogaćivanjem niskoprocentne rude gvožđa iz rudnog ležišta Rouina, Ajn Delfa. Ova ruda se trenutno koristi u cementnoj industriji zato što se smatra rudom gvožđa niskog sadržaja. Nakon uzorkovanja izvršena je fizičko-hemijska i mineraloška karakterizacija. Rezultati su pokazali da se uzorci sastoje od hematita, limonita i getita kao oksidnih minerala, silikata i gline iz minerala jalovine. Prosečni sadržaj $\mathrm{Fe}_{\text {Total, }} \mathrm{SiO}_{2}$ i $\mathrm{Al}_{2} \mathrm{O}_{3}$ u sirovini iz rudnika koja je korišćena u istraživanju bio je 30,85\%, 23,12\% i 7,77\%, respektivno. Postupci koji uključuju klasifikaciju, ispiranje i suvu magnetnu separaciju visokog intenziteta su sprovedeni radi obogaćivanja uzorka niskoprocentne rude gvožđa kako bi ga učinili pogodnim za tržište. Uzorak je prvo usitnjen, zatim je svaki prosejani deo ispran $i$ osušen, i nakon toga je podvrgnut postupku suve magnetne separacije visokog intenziteta. Primećeno je da je delimično obogaćivanje rude moguće. Rezultati su pokazali da je moguće dobiti magnetni koncentrat od $54,09 \%$ sa stepenom iskorišćenja $89,30 \%$ i iskorišćenjem od 62,82\% kada je jačina magnetnog polja 2,4 T, a klasa krupnoće [-0,125+0,063 mm].
\end{abstract}

Ključne reči: Rouina; Ruda gvožđa; Uzorkovanje; Karakterizacija; Ispiranje; Magnetna separacija. 